Original Research

\title{
Pollination Biology of Hemiboea ovalifolia (Gesneriaceae), an Endangered Herb from Guangxi, China
}

\author{
Gaozhong Pu, Yumei Pan, Chungqiang Wei, Saichun Tang* \\ Guangxi Key Laboratory of Plant Conservation and Restoration Ecology in Karst Terrain, Guangxi Institue of Botany, \\ Guangxi Zhuang Autonomous Region and Chinese Academy of Sciences, Guilin, China
}

Received: 15 January 2018

Accepted: 3 June 2018

\begin{abstract}
Although information on the reproductive biology of the endangered plant family Gesneriaceae is well known, the pollination mechanisms of these plants in karst regions are poorly understood. This study demonstrated the flowering phenology, pollinators, and breeding system of Hemiboea ovalifolia in karst regions. Findings revealed that the anthesis of $H$. ovalifolia often occurred late, during sunset, or early morning, with duration of 2-4 days; there was a certain level of temporal overlap between pollen viability and stigma receptivity; the most effective pollinators were Bombus ignitus and Anthophora zonata. Controlled pollination indicated that these plants were pollen limited and exhibited late-acting inbreeding depression resulting from the seed sets; there were significant differences in fruit sets between open-pollination and self-pollination or cross pollination, and in seed sets between self-pollination and cross-pollination or open-pollination. Despite the co-existence of large numbers of fruit and seed sets, and vegetative propagation in H. ovalifolia, a failure in seedling survival, and long duration to establishing first-year seedlings in natural populations suggests that the species does not easily recover from damage.
\end{abstract}

Keywords: endangered species, breeding system, Hemiboea ovalifolia, late-acting inbreeding depression

\section{Introduction}

Information on the biology of rare species and those with restricted geographical ranges is crucial for predicting their reproductive success, understanding their population dynamics, and suggesting appropriate conservation measures [1-3]. As one of the key

*e-mail: 417895168@qq.com contributing factors of a species becoming endangered, the plant breeding system has received the most widespread attention and can vary according to species distribution [4]. In general, both the direct and indirect changes in habitat fragmentation can threaten the survival of endangered plants by reducing potential habitat and population viability, or disrupting plant pollinator interactions [1, 5-6]. However, small and isolated plant populations have been one of the problems that scientists have been arguing about for a long time [7-8]. 
A host of plants maintain mixed mating systems that permit both self- and cross-fertilization; each mode of sexual reproduction has associated advantages and disadvantages [9]. In general, rare plants may be limited by reduced reproduction and exhibit slightly higher levels of self-compatibility compared with more common plants. Due to selective advantages, selfing provides reproductive assurance during colonization processes, bottlenecks, times of scarce or unreliable pollinators, and instances of two-fold gene transmission [1, 10-11]. Previous studies indicate that the breeding system of many rare plants may combine selfing with crossing - sometimes in a form of vegetative propagation [10, 12-13]. Meanwhile, many rare plants, characterized by small and isolated plant populations, may be less conspicuous for pollinators, which leads to fewer visits, changes in pollinator behavior, disruption of plant-pollinator interactions, and reduced reproductive success $[4,8]$. In addition, reductions in pollinators may directly affect trade-offs by influencing reproductive output, reducing the quantity and/or quality of fruit and seed sets, and promoting selfing in self-compatible species [14].

Gesneriaceae is a highly abundant and diverse plant family in China; it contains a reported 59 (27 endemic) genera and 460 (375 endemic) species [15]. Flowers in this family are highly diversified, reflecting adaptation to a wide range of pollinators including bees, birds, and bats [15-18]. Although widespread research has been conducted on the reproductive biology of Gesneriaceae [17-20], little is known about the pollination biology of endangered species in this family from China, where more than half the species exist in a restricted geographical area. Furthermore, a host of Gesneriaceae species have significant ornamental or medicinal values; consequently, these species have high conservation and scientific value [21]. It is therefore important to understand the reproductive biology of these species. Hemiboea ovalifolia (W.T. Wang) A. Weber and Mich. Möller. [22], a perennial herb that can grow up to 200 $\mathrm{cm}$ in height, is endemic solely to southwestern China [22-24], and is one of the four endemic species of the family listed in the China Red Book [23]. Based on molecular data and morphology, the genus Metabriggsia is reduced to synonymy with Hemiboea, and two species have been transferred to this genus [22]. The chromosome number $(2 n=24)$, geographic distribution, and tissue culture of $H$. ovalifolia have been previously assessed [22-27]. However, despite its conservation status, rarity, and occurrence in a protected area, to the best of our knowledge no information is available on its reproductive biology.

Hence, the present study aimed to clarify the pollination ecology of $H$. ovalifolia. Our specific objectives were to: (a) describe its floral morphology and phenology, (b) identify candidate pollinators and ascertain any pollinator limitation, (c) describe its breeding system, and (d) examine the implications of these characteristics for its conservation.

\section{Materials and Methods}

\author{
Species and Sites
}

Plants of $H$. ovalifolia, were studied in montane rainforests on the limestone hills of Mulun National Nature Reserve $\left(25^{\circ} 07^{\prime} 01^{\prime \prime}\right.$ to $25^{\circ} 12^{\prime} 22^{\prime \prime} \mathrm{N}, 107^{\circ} 54^{\prime} 01^{\prime \prime}$ to $108^{\circ} 05^{\prime} 51^{\prime \prime}$ E) over an altitude range of $625-1000$ $\mathrm{m}$ in Huanjiang county, Guangxi, China. Plants of $H$. ovalifolia across the whole altitude range were observed and the numbers of buds of old plants were counted. Data from the Plant Protection Station of the Agricultural Bureau in Huanjiang County of Guangxi Zhuang Autonomous Region, the nearest weather station, revealed that the location has an annual mean temperature of $17-19.3^{\circ} \mathrm{C}$, with August being the warmest $\left(28^{\circ} \mathrm{C}\right)$ and February the coldest $\left(-5.3^{\circ} \mathrm{C}\right)$. The location has an annual rainfall of $1750 \mathrm{~mm}$, with June being the wettest $(260 \mathrm{~mm})$ and December the driest $(70 \mathrm{~mm})$. In the study area, $H$. ovalifolia is found growing on rocky outcrops, with a sparse cover over trees and shrubs such as Choerospondias axillaris (Roxb) Burtt and Hill, Itoa oreintalis Hemsl, Schefflera octophylla (Lour) Harms, Begonia cavaleriei Lévl, and Elatostema sublineare Wang. $H$. ovalifolia commonly established as a uniform patch of plants covering an area of up to $25 \mathrm{~m}^{2}$ and comprising up to 40 individual plants. It flowers in autumn, from October to November; flowers are bisexual and occur in axillary cymes.

\section{Flowering Process and Flower Visitation}

To observe the flowering process, three flowers on each study plant $(n=20)$ were marked as buds at each location. From anthesis, observations were made at approximately 2-hour intervals during daylight hours between 06:00 and 18:00 on the first day, and between 09:00 and 18:00 over the next 2 days. For each flower, corolla color was recorded and the spatial distribution of floral organs was observed under a stereomicroscope. Additionally, five flowers were collected at each observation time to provide material for pollen viability and stigma receptivity testing. Observations and tests were conducted on this site between October 16 and November 15, 2006, and repeated between October 21 and November 20, 2008. Pollen grains were stained with dimethylthiazol diphenyl tetrazolium bromide to test for the presence of dehydrogenase as an indicator of pollen viability. Stigma receptivity was determined by the $\mathrm{H}_{2} \mathrm{O}_{2}$-catalase method of Dafni [28]. Between October 11-16, 2006 and October 25-29, 2008, the identity and number of pollinating insects were recorded on up to 20 flowers per observation between 09:00 and 18:30 each day. A total of 80 hours of observations were made each year. All pollinators and their behaviors were recorded, and then each pollinator was captured for identification. 


\section{Breeding System}

In both years, several pollination treatments were applied to individual plants in two populations of $H$. ovalifolia as follows: (1) cross-pollination, 35 flowers of 11 plants were hand pollinated with pollen from another individual; (2) self-pollination, a total of 35 flowers of 10 plants were self-pollinated by placing flower pollinia onto the stigmas of the same plant; (3) open-pollination, 30 untreated control flowers from ten plants; (4) pollen-stigma interference, stamens from 30 flowers of 10 plants were removed; (5) pollinatorexclusion, 30 flowers of 10 plants were bagged for spontaneous self-pollination testing; (6) perianth removal, the perianths were removed from buds just before anthesis, and the buds were then left exposed; and (7) agamospermy, stamens or stigma were removed

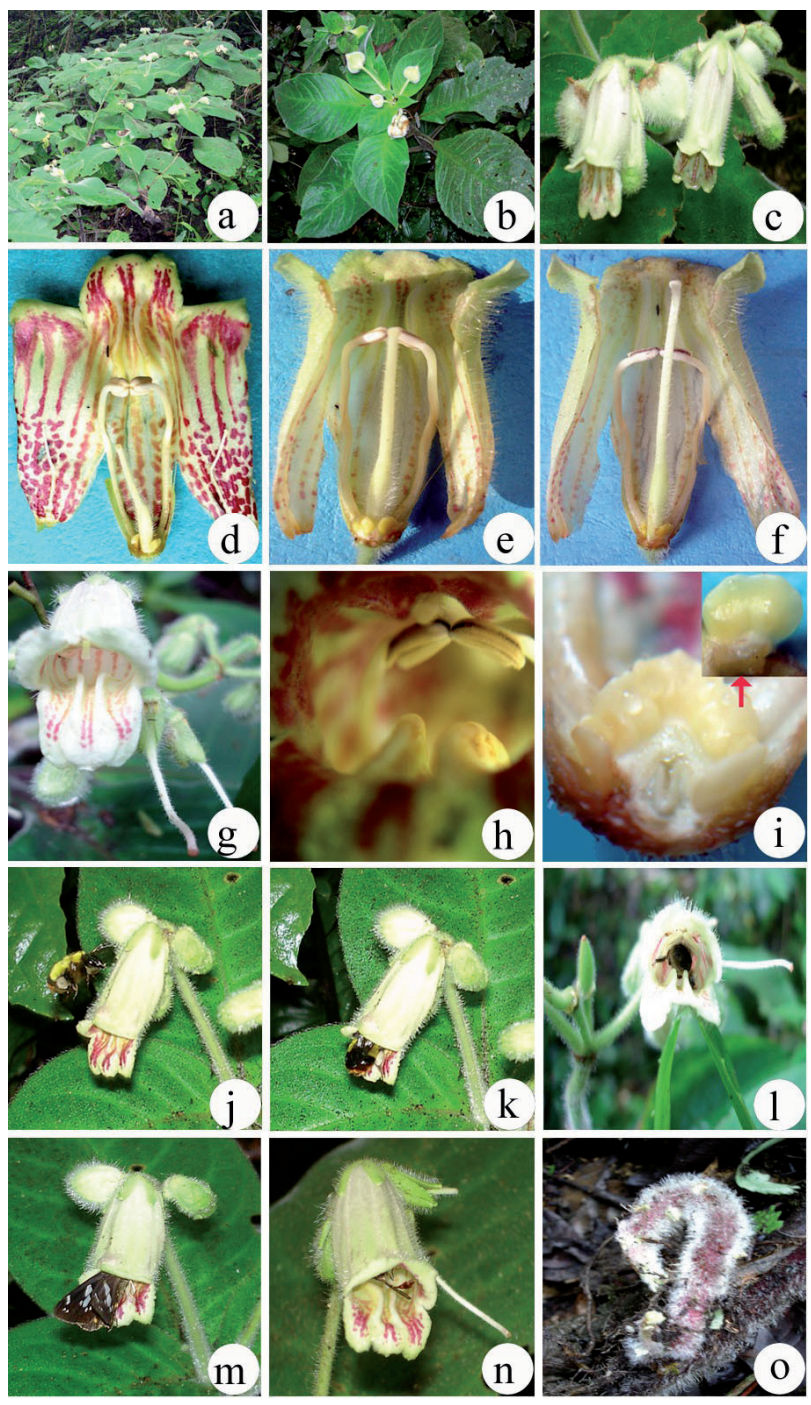

Fig. 1. Floral syndrome and pollinators of $H$. ovalifolia. a-c, Flowering of $H$. ovalifolia; d-f, the process of development and curve of style after flowering; g-h, flower; i, nectary; j-1, Bombus speciosus and Anthophora zonata visiting H. ovalifolia; m, Celoenorrhinus asperses Leech visiting H. ovalifolia; n, Ophion sp. visiting $H$. ovalifolia; and o, radical bud. from buds just before anthesis, and the buds were then enclosed in bags. The number of seedlings and root sprouts per plant were counted at five $10 \times 10 \mathrm{~m}$ sites in 2009.

\section{Statistical Analysis}

Means $( \pm \mathrm{SE})$ were calculated for all measurements using Excel 2010 (Microsoft). Pollen viability, stigma receptivity, and fruit set and seed number were compared between different pollination treatments using one-way analysis of variance in SPSS (version 18.0). Statistically significant differences were set at $P<0.05$ unless otherwise stated.

\section{Results}

Flowering Phenology, Pollen Viability, and Stigma Receptivity

H. ovalifolia flowers are shown in Fig. 1(a-n). The mean ( \pm standard error [SE]) number of inflorescences the plant produces is $7.36 \pm 0.24$ (range $3-15, \mathrm{n}=20$ ). Flowering of the whole population occurred between early October and late November. Flowers opened during early morning (04:00-05:00) or late afternoon (18:00-19:00), and remained open for 2-4 days depending on environmental conditions. Once a flower was pollinated, the corolla and attached anthers fell off the following day, while un-pollinated flowers remained open for up to 4 days before the corollas wilted and closed (Fig. 1g). The fruits matured approximately 1 month later.

Mean pollen viability $( \pm$ SE) was $19.4 \pm 2 \%$, when flowers were in anthesis (Fig. 2). Ten hours after flowering, stigmas were white and had lower receptivity. Twenty hours after flowering, both pollen viability and stigma receptivity were high during the flowering

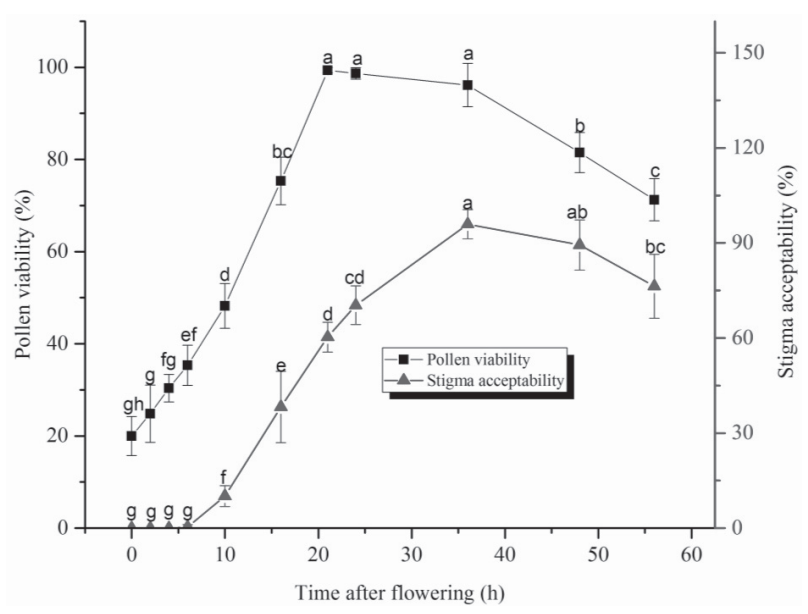

Fig. 2. Changes of pollen viability and stigma receptivity in H. ovalifolia; different lowercase letters on the top of the bars denote significant differences $(P<0.05)$. 
period, while 40 hours after the initiation of flowering, both pollen viability and stigma receptivity decreased (Fig. 2).

\section{Flower Visitors}

During a total of 80 observation hours, four pollinators, including three bee species (Fig. 1j-1, n) and one butterfly species (Fig. 1m), were recorded visiting $H$. ovalifolia flowers. The two most effective pollinators were Bombus ignitus Smith and Anthophora zonata $\mathrm{L}$. This is because, when visiting $H$. ovalifolia flowers, their head and back made contact with the stigma first, followed second by the anthers; this caused pollen grains to stream out of the anthers. Mean $( \pm$ SE) visiting frequency of $B$. speciosus and A. zonata was $0.783 \pm 0.013$ flower $^{-1}$.hour ${ }^{-1}$ and $0.583 \pm 0.017$ flower $^{-1}$. hour ${ }^{-1}$, respectively. These two pollinators visited flowers primarily during the morning, with peak visits occurring at 10:00-12:00 and 14:00-16:00 (Fig. 3). Celoenorrhinus asperses Leech was also an effective pollinator, with frequently recorded visits to the flowers $\left(0.167 \pm 0.007\right.$ flower $^{-1}$.hour $\left.{ }^{-1}\right)$, and body contact was made with the stigma and anthers (Fig. 1m). Ophion sp. was only considered an occasional visitor since behaviors such as pollen collection, nectar consumption, stigma touching, and grooming were not observed (Fig. 1n).

\section{Breeding System}

Hemiboea ovalifolia combined sexual reproduction with vegetative propagation. In sexual reproduction, the pollination treatments revealed that $H$. ovalifolia was self-compatible. Both cross- and self-pollination produced a large number of fruit sets and there were no significant differences in fruit set numbers between these two types of pollination (Fig. 4), while there

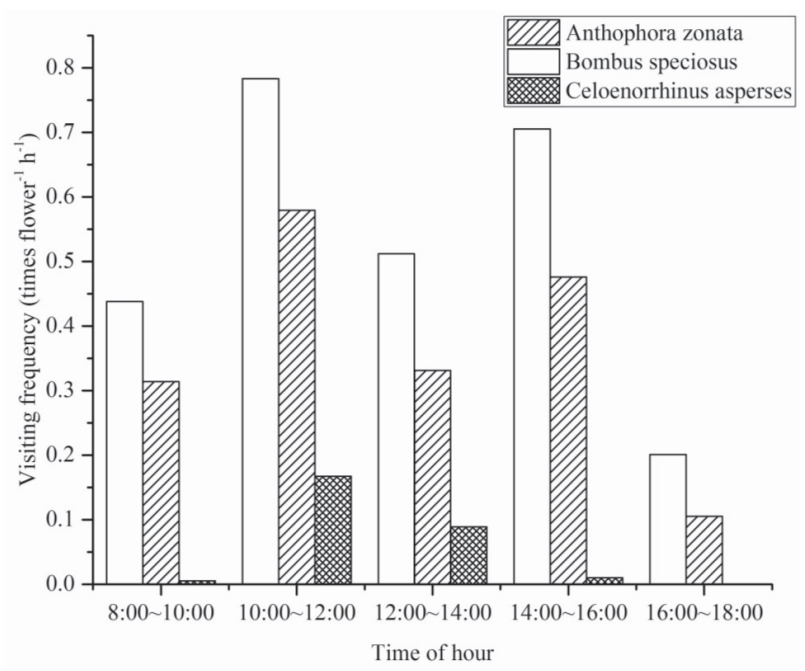

Fig. 3. Frequency of visits by Bombus speciosus, Anthophora zonata, and Celoenorrhinus asperses Leech to flowers of H. ovalifolia during $80 \mathrm{~h}$ of observation of 20 plants.

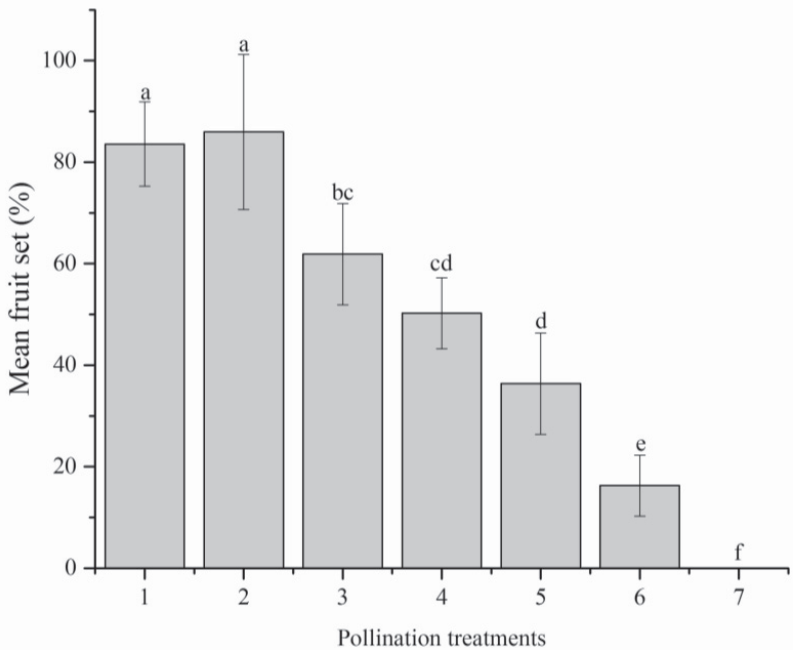

Fig. 4. Mean ( \pm standard error) fruit set of $H$. ovalifolia inflorescences subjected to seven pollination treatments: 1) cross-pollination, 2) self-pollination, 3) open-pollination, 4) pollen-stigma interference, 5) pollinator exclusion, 6) perianthremoved, and 7) agamospermy; different lowercase letters on the top of the bars denote significant differences $(\mathrm{n}=6, P<0.05)$.

were significant differences in fruit sets between open-pollination and self-pollination or cross-pollination $(t=-4.24, d f=10, P=0.005$ and $t=-4.74, d f=10$, $P=0.003$, respectively). Pollinator-exclusion and perianth removal treatment significantly reduced the number of fruit sets, and significant differences in the number of fruit sets were observed between these two treatments $(t=-6.74, d f=10, P<0.001$; Fig. 4). Furthermore, open-pollinated flowers produced significantly fewer seeds than cross-pollination, openpollination, pollen-stigma interference, and perianth

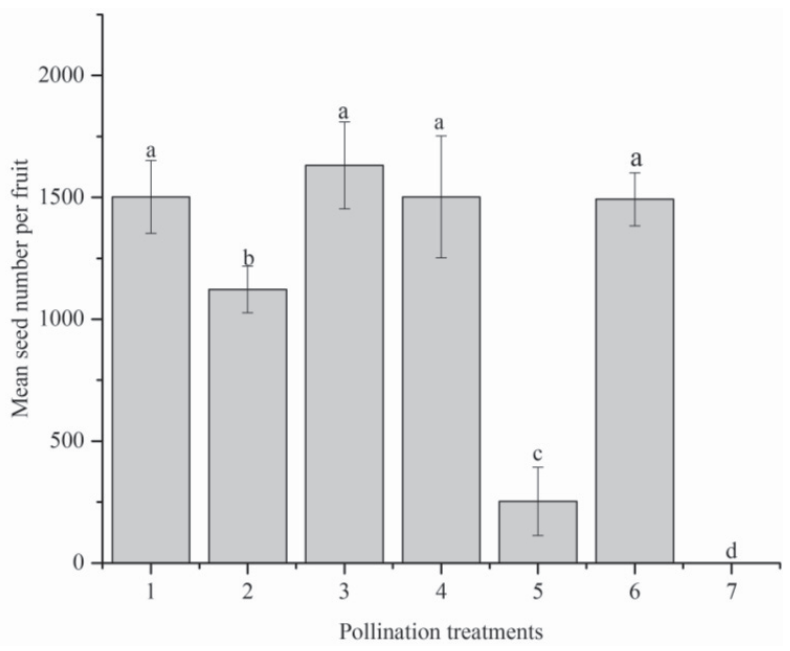

Fig. 5. Mean ( \pm standard error) seed number per $H$. ovalifolia fruit resulting from seven pollination treatments: 1) cross-pollination, 2) self-pollination, 3) open-pollination, 4) pollen-stigma interference, 5) pollinator-exclusion, 6) perianth-removed, and 7) agamospermy. different lowercase letters on the top of the bars denote significant differences $(\mathrm{n}=6, P<0.05)$ 
removal treatments (Fig. 5). In agamospermy treatment, no fruit and seed sets were observed (Figs 4-5).

In regard to vegetative propagation, $H$. ovalifolia has evolved a survival strategy by means of a thick perennial rhizome-like root stock (Fig. 10). In this field investigation, the species was recorded as population with a narrow geographic distribution comprising a mean $( \pm \mathrm{SE})$ of only $50 \pm 8$ individual plants $(n=5)$. The number of buds of the root stock from the old stock was higher than the number of seedlings $\left(10 \pm 4\right.$ buds vs. $4 \pm 2$ seedlings every $\left.100 \mathrm{~m}^{2}\right)$. Furthermore, the establishment of flowering $H$. ovalifolia from seedlings or root sprouts took approximately 3-4 years.

\section{Discussion of Results}

Previous studies have indicated that pollen limitation was common in angiosperm species [29-31] and in some Gesnerioideae species found in karst regions with restricted geographical distribution [15, 17, 19-20, 32]. In the present study, pollination experiments showed that there were significant differences in the number of fruit sets between open-pollinated samples and artificially fertilized flowers (both cross- and self-pollination), suggesting that the population investigated experiences a degree of pollen limitation. Since pollen limitation is a significant determinant of seed production [33], a potential explanation for this pollen limitation may be due to low pollination quantity and/or quality. There were no significant differences in fruit sets between cross-pollination and self-pollination, but significant differences in seed sets, indicating that pollen quality may be a possible cause of pollen limitation in $H$. ovalifolia. Since there were significant differences in the number of fruit sets between cross-pollination, openpollination, and perianth removal, but no significant differences in seed sets, this suggests that insufficient pollen quantity may not affect seed sets.

The coexistence of dichogamy and herkogamy is generally considered to promote cross pollination and avoid sexual conflict [34]. The present study showed that there was spatial and temporal gender separation in the flowering process of $H$. ovalifolia, indicating strong temporal protandry (dichogamy) and complete spatial separation between male and female function within each flower (herkogamy). However, there was a certain level of temporal overlap between pollen viability and stigma receptivity; pollinator exclusion treatments sharply reduced the number of fruit and seed sets, suggesting a certain degree of spontaneous self-pollination in $H$. ovalifolia. This phenomenon has also been reported in other geographically restricted Gesnerioideae species in karst regions, such as Dayaoshania cotinifolia W. T. Wang [17]. Furthermore, the present pollination experiments showed that there were no significant differences in fruit sets between the cross- and self-pollination treatments, but there were significant differences in seed sets, and that the pollinator exclusion treatment produced the lowest number of fruit and seed sets (except when the stigma was removed) in $H$. ovalifolia. These results suggest that the breeding system of $H$. ovalifolia is predominantly cross-pollination with partly spontaneous self-pollination, but without apomixes (stigma removal treatment did not produce fruit or seed sets).

Although the maximum proportion of fruit sets following open pollination was recorded at $61.87 \%$, the field investigation results showed that there were only a few seedlings growing around the old one, suggesting a failure in seed germination in natural H. ovalifolia populations. One possible reason may due to the occurrence of late-acting inbreeding depression. Our results showed that both self-pollination and pollinator exclusion treatments produced the lowest quality of seed sets despite the highest fruit sets. This suggests the existence of late-acting inbreeding depression in $H$. ovalifolia since the low quality of the offspring could lead to low seed germination or increased seedling mortality due to the expression of deleterious alleles [33, 35-36]. In addition, although the field investigation revealed that the number of buds from the root stock of $H$. ovalifolia was 2.5 -fold greater than the number of seedlings, the establishment of flowering $H$. ovalifolia from seedlings or buds took approximately 3-4 years. This indicates that this species does not easily recover once damaged.

\section{Conclusions}

H. ovalifolia was self-compatible and the population investigated experienced a degree of pollen limitation, which may contribute to the low pollination quality since there were same fruit sets in both cross-pollination and self-pollination treatments but low seed sets only in self-pollination treatments. The breeding system of $H$. ovalifolia is predominantly cross-pollination with partly spontaneous self-pollination, but without apomixes (stigma removal treatment did not produce fruit or seed sets). Despite the existence of asexual reproduction in $H$. ovalifolia, a failure of seed germination and a narrow restricted population indicated that the species was not easy to recover once damaged. Therefore, the preservation of its habitats is the most critical aspect in any strategies for the conservation of H. ovalifolia.

\section{Acknowledgements}

This project is supported by the National Natural Science Foundation of China (31860023), the Guangxi Scientific and Technological Project (Guikezhong1598014-3), and the Natural Science Foundation of Guangxi Province (2015GXNSFEA139001 and 2015GXNSFAA139072). 


\section{Conflict of Interest}

The authors declare no conflict of interest

\section{References}

1. RODRIGUEZ-PEREZ J. Breeding system, flower visitors and seedling survival of two endangered species of Helianthemum (Cistaceae). Annals of Botany London, 95, 1229, 2005.

2. CLIVATI D., CORDEIRO G.D., PŁACHNO B.J., DE MIRANDA V.F.O. Reproductive biology and pollination of Utricularia reniformis A.St.-Hil. (Lentibulariaceae). Plant Biology, 16, 677, 2014.

3. SU Z., RICHARDSON B. A., ZHUO L., JIANG X. Divergent population genetic structure of the endangered Helianthemum (Cistaceae) and its implication to conservation in northwestern china. Frontiers in Plant Science, 7, 2010, 2016.

4. ECKERT C.G., KALISZ S., GEBER M.A., SARGENT R., ELlE E., CHEPTOU P.O., GOODWILlIE C., JOHNSTON M.O., KELLY J.K., MOELLER D.A., PORCHER E., REE R.H., VALLEJO-MARÍN M., WINN A.A. Plant mating systems in a changing world. Trends in Ecology \& Evolution, 25 (1), 35, 2010.

5. NICOLSON S.W., WRIGHT G.A. Plant-pollinator interactions and threats to pollination: perspectives from the flower to the landscape. Functional Ecology, 31 (1), 22, 2017.

6. WANG W., QIAO Y., LI S., PAN W., YAO M. Low genetic diversity and strong population structure shaped by anthropogenic habitat fragmentation in a critically endangered primate, Trachypithecus leucocephalus. Heredity, 118(6), 542, 2017.

7. ABELI T. Survival of small isolated plant populations: an integrated approach to evaluate population viability for future conservation actions. Scientifica Acta, 4 (1), 3, 2010.

8. MEEUS S., HONNAY O., JACQUEMYN H. Differences in fine-scale spatial genetic structure across the distribution range of the distylous forest herb Pulmonaria officinalis (Boraginaceae). BMC Genetics, 14, 1, 2013.

9. VAN DRUNEN W.E., DORKEN M.E. Trade-offs between clonal and sexual reproduction in Sagittaria latifolia (Alismataceae) scale up to affect the fitness of entire clones. New Phytologist, 196, 606, 2012.

10. MINUTO L., GUERRINA M., ROCCOTIELLO E., ROCCATAGLIATA N., MARIOTTI M.G., CASAZZA G. Pollination ecology in the narrow endemic winterflowering Primula allionii (Primulaceae). Journal of Plant Research, 127, 141, 2013.

11. SCHOUPPE D., BRYS R., VALLEJOMARIN M., JACQUEMYN H. Geographic variation in floral traits and the capacity of autonomous selfing across allopatric and sympatric populations of two closely related Centaurium species. Scientific Reports, 7, 46410, 2017.

12. JIMÉNEZ A., MANSOUR H., KELLER B., CONTI E. Low genetic diversity and high levels of inbreeding in the Sinai primrose (primula boveana), a species on the brink of extinction. Plant Systematics \& Evolution, 300 (5), 1199, 2014.

13. 1ROGALSKI J.M., REIS A., ROGALSKI M., MONTAGNA T., DOS REIS M.S. Mating system and genetic structure across all known populations of Dyckia brevifolia: a clonal, endemic and endangered rheophyte bromeliad. Journal of Heredity, 108 (3), 299, 2017.

14. SPIGLER R.B., KALISZ S. Persistent pollinators and the evolution of complete selfing. American Journal of Botany, 104 (12), 1783, 2017.

15. LING S.J., MENG Q.W., TANG L., REN M.X. Pollination syndromes of Chinese Gesneriaceae: a comparative study between hainan island and neighboring regions. Botanical Review, 83 (1), 1, 2017.

16. GAO J.Y., REN P.Y., YANG Z.H., LI Q.J. The pollination ecology of Paraboea rufescens (Gesneriaceae): a buzzpollinated tropical herb with mirror-image flowers. Annals of Botany London, 97, 371, 2006.

17. WANG Y.B., LIANG H.W., MO N.B., QIN K.P., TANG G.G. Flower Phenology and Breeding System of Rare and Endangered Dayaoshania cotinifolia. Acta Botanica Boreali-Occidentalia Sinica, 31, 0861, 2011 [In Chinese].

18. SERRANO-SERRANO M.L., ROLLAND J., CLARK J.L., SALAMIN N., PERRET M. Hummingbird pollination and the diversification of angiosperms: an old and successful association in Gesneriaceae. Proceedings of the Royal Society B: Biological Sciences, 284 (1852), 20162816, 2017.

19. PU G.Z., PAN Y.M., TANG S.C., WEI C.Q., CHEN Q.X. Pollination Biology and Reproductive Allocation of Chirita gueilinensis (Gesneriaceae). Bulletin of Botanical Research, 29, 169, 2009 [In Chinese].

20. WEN F., FU L.F., WEI Y.G. Pollination biology of Primulina repanda var. guilinensis and P. glandulosa var. yangshuoensis. Guihaia, 32, 571, 2012 [In Chinese].

21. HOU N., WANG G., LI C.R., LUO Y. Characterization of the complete chloroplast genomes of three Chirita species (C. brachytricha, C. eburnea, \& C. liboensis ) endemic to china. Conservation Genetics Resources, 1, 2017.

22. WEBER A., WEI Y.G., SONTAG S., MÖLLER M. Inclusion of Metabriggsia into Hemiboea (Gesneriaceae). Phytotaxa, 23, 37, 2011.

23. OU Y., LV J., SILVA J.A.T. D., MA G. Vegetative propagation of Metabriggsia ovalifolia W. T. Wang using leaf cuttings and petiole segments. Journal of Pomology \& Horticultural Science, 90 (6), 724, 2015.

24. WANG W.T. Genus novum Gesneriacearum e Guangxi. Guihaia, 3, 1, 1983 [In Chinese].

25. CAO M., LIN C.R., TANG S.C., WEI Y.G. Pollen morpholoy of some species Gesneriaceae from Guangxi. Guihaia, 23, 139, 2003 [In Chinese].

26. MA G.H., DA SILVA J.A.T., LV J.F., ZHANG X.H., ZHAO J.T. Shoot organogenesis and plant regeneration in Metabriggsia ovalifolia. Plant Cell Tissue and Organ Culture, 105, 355, 2011.

27. OUYANG Y., CHEN Y., LÜ J., SILVA J. A. T. D., ZHANG $\mathrm{X}$., MA G. Somatic embryogenesis and enhanced shoot organogenesis in Metabriggsia ovalifolia W. T. Wang. Scientific Reports, 6 (24662), 9, 2016.

28. DAFNI A. Pollination Ecology, a Practical Approach. Oxford University Press, Oxford, New York, 250, 1992.

29. KNIGHT T.M., STEETS J.A., VAMOSI J.C., MAZER S.J., BURD M., CAMPBELL D.R., DUDASH M.R., JOHNSTON M.O., MITCHELL R.J., ASHMAN T.L. Pollen limitation of plant reproduction: pattern and process. Annual Review of Ecology, Evolution, and Systematics, 36, 467, 2005.

30. PEARSE I.S., KOENIG W.D., FUNK K.A., PESENDORFER M.B. Pollen limitation and flower abortion in a wind-pollinated, masting tree. Ecology, 96, 587,2015 
31. HUANG Q., BURD M., FAN Z. Resource allocation and seed size selection in perennial plants under pollen limitation. American Naturalist, 190 (3), 430, 2017.

32. MARTÉN-RODRÍGUEZ S., QUESADA M., CASTRO A., LOPEZARAIZA-MIKEL M., FENSTER C.B. A comparison of reproductive strategies between island and mainland Caribbean Gesneriaceae. Journal of Ecology, 103 (5), 1190, 2015.

33. RODGER J.G., ELLIS A.G. Distinct effects of pollinator dependence and self-incompatibility on pollen limitation in South African biodiversity hotspots. Biology Letters, 12 (6), 20160253, 2016

34. LLOYD S., VELLEND M. Herbivory and pollen limitation at the upper elevational range limit of two forest understory plants of eastern North America. Ecology \& Evolution. 1, 2017.

35. MENA-ALÍ J.I., ROCHA O.J. Selective seed abortion affects the performance of the offspring in Bauhinia ungulata. Annals of Botany London, 95, 1017, 2005.

36. DUARTE M.O., MENDES-RODRIGUES C., ALVES M.F., OLIVEIRA P.E., SAMPAIO D.S. Mixed pollen load and late-acting self-incompatibility flexibility in Adenocalymma peregrinum (miers) L.G. Lohmann (Bignonieae: Bignoniaceae). Plant Biology, 19 (2), 140, 2016. 
